\title{
Notes on the Wild Tomistoma Populations in Western Sarawak, Malaysian Borneo
}

\author{
Ruhana Hassan, ${ }^{1}$ Rambli Ahmad, ${ }^{2}$ Muhammad Amirul Arib Md Adzhar, ${ }^{1}$ \\ Mohd Izwan Zulaini Abdul Gani, ${ }^{1}$ Anuar Ayob, ${ }^{3}$ and Ramlah Zainudin ${ }^{4}$ \\ ${ }^{1}$ Department of Aquatic Science, Faculty of Resource Science and Technology, Universiti Malaysia Sarawak, \\ 94300 Kota Samarahan, Sarawak, Malaysia \\ ${ }^{2}$ Sarawak Forestry Corporation Sdn. Bhd., Lot 218, KCLD, Jalan Tapang, Kota Sentosa, 93250 Kuching, Sarawak, Malaysia \\ ${ }^{3}$ Department of Visual Art and Technology, Faculty of Applied and Creative Arts, Universiti Malaysia Sarawak, \\ 94300 Kota Samarahan, Sarawak, Malaysia \\ ${ }^{4}$ Department of Zoology, Faculty of Resource Science and Technology, Universiti Malaysia Sarawak, \\ 94300 Kota Samarahan, Sarawak, Malaysia
}

Correspondence should be addressed to Ruhana Hassan; hruhana@unimas.my

Received 29 April 2016; Revised 8 September 2016; Accepted 21 September 2016

Academic Editor: Panos V. Petrakis

Copyright (c) 2016 Ruhana Hassan et al. This is an open access article distributed under the Creative Commons Attribution License, which permits unrestricted use, distribution, and reproduction in any medium, provided the original work is properly cited.

\begin{abstract}
Tomistoma schlegelii, the Freshwater Malayan Gharial or Tomistoma (local name: buaya jejulong), is secretive in nature; thus, very limited information is currently available on its wild population, especially in Sarawak. The objective of this study is to describe effort in assessing the Tomistoma wild populations in Ulu Sebuyau, Samarahan, and Serian, western Sarawak. Despite many challenges faced, this research has been successful at different levels. There was no Tomistoma seen during day surveys (2014-2015) in tributary of Samarahan River (Samarahan), Bunga-Baki River (Serian), and Kepayang River (Ulu Sebuyau). However, the research team came across two incidents of Tomistoma captured by the local people: (i) an adult male Tomistoma, captured in February 2015 in peat swamp area of Samarahan River tributary, and (ii) a hatchling, caught in Bunga-Baki River in March 2015. The sightings of Tomistoma in Kepayang River were reported by local people in February 2016; however, no individual was captured. The presence of hatchling in Bunga-Baki River indicates that a breeding population is most likely to occur in the area, and this gives hope for future conservation of Tomistoma in Sarawak. All sampling sites recorded almost similar water quality parameters and landscape of peat swamp areas, which previous studies claimed to be the potential Tomistoma habitats. The findings of this study should help relevant state agencies to step up efforts related to conservation of Tomistoma in Sarawak.
\end{abstract}

\section{Introduction}

Tomistoma schlegelii is also known by English common name as Freshwater Malayan Gharial or False Gharial or Tomistoma or Sunda Gharial whereas its local name in Sarawak is "buaya jejulong." This species is listed under International Union for Conservation of Nature (IUCN) Red List as vulnerable species [1] and listed under Appendix I of the Convention on International Trade in Endangered Species of Wild Flora and Fauna (CITES). In Peninsular Malaysia, it is protected under Wildlife Conservation Act 2010. It is also listed as a Protected Animal in the Sarawak Wild Life Protection Ordinance
(1998); hence, any hunting, killing, or selling of wild Tomistoma in the state is prohibited.

Literatures claimed that Tomistoma inhabits Indonesia, Malaysia, possibly Vietnam, and Thailand [2]. However, very limited information is known about Tomistoma in Sarawak. In previous literature, [3] reported that the status of its population in Sarawak is unclear. Other than that, [4] had produced a brief documentation on the existence of Tomistoma in Sarawak, in which it stated that this species can be found in Ensengai River and Keluh River. Meanwhile, [5] produced reports on status and conservation on Tomistoma in Southeast Asia, but it reported very limited information regarding 
this species in Sarawak. Furthermore, the authors of [6] had compiled records of Tomistoma in Malaysia based on historical information and personal communications with scientists and local people. They also highlighted that some Tomistomas are currently being held in captivity for ex situ conservation purpose in zoos and private farms. Sixteen rivers in Sarawak had been claimed as habitats of Tomistoma (1917 to 2003), mostly with small number of Tomistoma individuals. Meanwhile, the author of [7] had carried out Tomistoma surveys in Engkilili, Maludam National Park, and Loagan Bunut and it reported that one individual was spotted in Engkilili but none in other areas. His project has limited success to verify the population status of Tomistoma in Sarawak, although the state has many potential Tomistoma habitats. In terms of conservation priorities for Tomistoma wild populations in its geographical range, Sarawak is categorized as "moderate priority" [1].

Threats to Tomistoma came mostly from conversion of peat lands and pandan swamps (black water area with Pandanus palms as the common flora) into agriculture [6], not due to hunting, because the skin of Tomistoma is of less value commercially and rarely people consume the meat. Due to secretive nature of this species, attacks were most probably due to opportunistic killing rather than aggressive nature of hunting [8]. The species is generally regarded as harmless to humans, although one case of attack on humans has been confirmed and others have been reported. Similarly, local people in Sarawak regarded Tomistoma as peaceful animal that should be left alone but precaution steps are still needed to ensure safety of both humans and animals. The species is generally regarded as harmless to humans, with only small number of reported human-Tomistoma conflicts in Sarawak, but could also cause human fatality, for example, the one that happened in Tisak River [8].

People of Sarawak and Malaysia are so proud to be in the map where Tomistoma is reported to be found, yet this species only appeared in folklores told by older generation living in upper areas of selected rivers. This paper describes efforts made to locate Tomistoma wild populations in western part of Sarawak (2014-2015), which hopefully will lead to Tomistoma conservation actions in Sarawak in the near future.

\section{Materials and Methods}

\subsection{Wild Populations Survey}

2.1.1. Field Visits. Paper [8] claimed that Sadong River and other nearby rivers in Simunjan and Ulu Sebuyau, Sarawak, have many potential Tomistoma habitats. Thus, three sites had been chosen (Figure 1) in Kepayang River (Ulu Sebuyau), tributary of Samarahan River, and Bunga-Baki River (Serian). For Kepayang River, surveys had been conducted in separate visits, that is, 22nd-25th July 2014, 4th-5th December 2014, and 3rd-4th February 2015. For Samarahan River, field visits were done on 14th and 15th February 2015 and for BungaBaki River, the visits were done on 21st and 22nd March 2015. All visits were carried out at the end of wet season (Northeast Monsoon), except for July 2014 trip for Kepayang

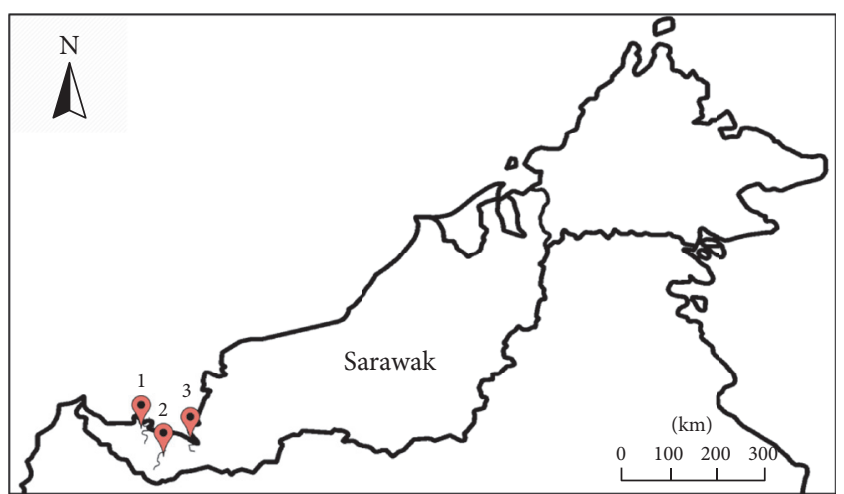

FIGURE 1: Sampling area in western part of Sarawak: 1: Samarahan River, 2: Bunga-Baki River, and 3: Kepayang River.

River. Due to limited accessibility of all sites, surveys were carried out using boats in the rivers as well as on foot along the riverbanks. Many stretches of the rivers were impossible to pass through due to overgrown weeds as well as the presence of water gates to control water levels in the rivers, possibly for agricultural purposes. All Tomistoma surveys were carried out during day time only.

\subsubsection{Study Area}

Samarahan River (Samarahan). The Samarahan River is huge river with complex river connections with distance of more than $70 \mathrm{~km}$. The downstream is connected directly to the South China Sea, which experiences the intrusion of saltwater. The upstream part (tributary of Samarahan River) comprises peat swamp and small riverine forest. Three checkpoints were selected for water quality (WQ) measurement (Table 1), and Tomistoma surveys were done continuously between checkpoints. The selection of checkpoints were based on natural river landscape observed. The tributary examined during this survey runs from the main river (Samarahan River) through oil palm estates (about $6 \mathrm{~km}$ ) followed by $4 \mathrm{~km}$ of small peat swamp forest. This tributary is approximately $12 \mathrm{~km}$ long with width of less than $10 \mathrm{~m}$. This tributary has very limited access due to overgrown weeds and other floating vegetations. Fishing seems to be of low intensity with some nets and set hooks seen, probably belonging to workers of the plantation. There was no boat traffic observed during the survey. No saltwater crocodiles were seen in this tributary although Samarahan River recorded a good number of human-crocodile conflicts [9], which resulted in both injuries and fatality.

Bunga-Baki River (Serian). The river is located near two villages, namely, Bunga Village and Baki Village. The river is relatively small in the upstream area, with approximately 2 to $3 \mathrm{~m}$ width, in contrast to the wider size in the downstream area ( 4 to $5 \mathrm{~m}$ ). The Bunga River flows from the mountain, into Baki River and later to Sadong River. The Bunga River flows through a forested landscape which has fairly clear water and comprises many rocky streams. The area is shaded with the forest trees; thus, the air temperature is relatively 
TABLE 1: Location and distance of rivers surveyed (on foot and using small boats).

\begin{tabular}{|c|c|c|c|c|c|}
\hline River & Checkpoint & Start & End & Distance & Tomistoma seen \\
\hline \multirow{3}{*}{ Samarahan River } & 1 & $\begin{array}{l}\mathrm{N} 1^{\circ} 25^{\prime} 17.4^{\prime \prime} \\
\mathrm{E} 110^{\circ} 32^{\prime} 16.0^{\prime \prime}\end{array}$ & $\begin{array}{l}\mathrm{N} 1^{\circ} 25^{\prime} 01.5^{\prime \prime} \\
\mathrm{E} 110^{\circ} 32^{\prime} 38.2^{\prime \prime}\end{array}$ & $857 \mathrm{~m}$ & 0 \\
\hline & 2 & $\begin{array}{l}\mathrm{N} 1^{\circ} 25^{\prime} 01.5^{\prime \prime} \\
\mathrm{E} 110^{\circ} 32^{\prime} 16.0^{\prime \prime}\end{array}$ & $\begin{array}{l}\mathrm{N} 1^{\circ} 24^{\prime} 38.5^{\prime \prime} \\
\mathrm{E} 110^{\circ} 34^{\prime} 10.9^{\prime \prime}\end{array}$ & $2.93 \mathrm{~km}$ & 0 \\
\hline & 3 & $\begin{array}{l}\mathrm{N} 1^{\circ} 24^{\prime} 38.5^{\prime \prime} \\
\mathrm{E} 110^{\circ} 34^{\prime} 10.9^{\prime \prime}\end{array}$ & $\begin{array}{l}\mathrm{N} 1^{\circ} 23^{\prime} 50.3^{\prime \prime} \\
\mathrm{E} 110^{\circ} 37^{\prime} 0.2^{\prime \prime}\end{array}$ & $5.43 \mathrm{~km}$ & 0 \\
\hline \multirow{2}{*}{ Bunga-Baki River } & 1 & $\begin{array}{c}\mathrm{N} 1^{\circ} 12^{\prime} 41.4^{\prime \prime} \\
\mathrm{E} 110^{\circ} 29^{\prime} 53.1^{\prime \prime}\end{array}$ & $\begin{array}{l}\mathrm{N} 1^{\circ} 13^{\prime} 25.7^{\prime \prime} \\
\mathrm{E} 110^{\circ} 30^{\prime} 36.5^{\prime \prime}\end{array}$ & $2.02 \mathrm{~km}$ & 0 \\
\hline & 2 & $\begin{array}{l}\mathrm{N} 1^{\circ} 13^{\prime} 37.3^{\prime \prime} \\
\mathrm{E} 110^{\circ} 30^{\prime} 31.8^{\prime \prime}\end{array}$ & $\begin{array}{l}\mathrm{N} 1^{\circ} 4^{\prime} 50.7^{\prime \prime} \\
\mathrm{E} 110^{\circ} 31^{\prime} 29.9^{\prime \prime}\end{array}$ & $2.82 \mathrm{~km}$ & 0 \\
\hline \multirow{4}{*}{ Kepayang River } & 1 & $\begin{array}{c}\mathrm{N} 1^{\circ} 23^{\prime} 01.3^{\prime \prime} \\
\mathrm{E} 110^{\circ} 55^{\prime} 13.5^{\prime \prime}\end{array}$ & $\begin{array}{l}\mathrm{N} 1^{\circ} 22^{\prime} 50.7^{\prime \prime} \\
\mathrm{E} 110^{\circ} 55^{\prime} 37.9^{\prime \prime}\end{array}$ & $1.29 \mathrm{~km}$ & 0 \\
\hline & 2 & $\begin{array}{c}\mathrm{N} 1^{\circ} 24^{\prime} 10.6^{\prime \prime} \\
\mathrm{E} 110^{\circ} 53^{\prime} 26.0^{\prime \prime}\end{array}$ & $\begin{array}{l}\mathrm{N} 1^{\circ} 23^{\prime} 58.8^{\prime \prime} \\
\mathrm{E} 110^{\circ} 53^{\prime} 59.8^{\prime \prime}\end{array}$ & $1.01 \mathrm{~km}$ & 0 \\
\hline & 3 & $\begin{array}{c}\mathrm{N} 1^{\circ} 21^{\prime} 27.2^{\prime \prime} \\
\mathrm{E} 110^{\circ} 55^{\prime} 38.4^{\prime \prime}\end{array}$ & $\begin{array}{l}\mathrm{N} 1^{\circ} 20^{\prime} 35.4^{\prime \prime} \\
\mathrm{E} 110^{\circ} 55^{\prime} 40.6^{\prime \prime}\end{array}$ & $525 \mathrm{~m}$ & 0 \\
\hline & 4 & $\begin{array}{l}\mathrm{N} 1^{\circ} 19^{\prime} 19.4^{\prime \prime} \\
\mathrm{E} 110^{\circ} 56^{\prime} 22.0^{\prime \prime}\end{array}$ & $\begin{array}{l}\mathrm{N} 1^{\circ} 19^{\prime} 19.3^{\prime \prime} \\
\mathrm{E} 110^{\circ} 56^{\prime} 31.9^{\prime \prime}\end{array}$ & $300 \mathrm{~m}$ & 0 \\
\hline
\end{tabular}

${ }^{*}$ Checkpoints: locations where water quality measurements were carried out. Tomistoma surveys were continuously carried out from one checkpoint to another in each river.

low (approximately $27^{\circ} \mathrm{C}$ ). Baki River flows through the peat swamps forest, with one village situated at the side of the river. The water has brown to black colour with slow flowing water. In general, the landscape, flora, and fauna compositions are common characters of a peat swamp area. Two checkpoints were selected during the survey (Table 1). Small scale fishing is the main activity in the river. Other than that, villagers use the river in daily activities, for example, as a means of transportation to tend their small agricultural plots located along the river banks. There is no palm oil plantation yet in the area, although the construction of concrete buildings and roads is rapid.

Kepayang River (Ulu Sebuyau). Four checkpoints were selected (Table 1 ). The river is approximately $15 \mathrm{~km}$ in length, between 2 and $4 \mathrm{~m}$ in depth, and approximately $10 \mathrm{~m}$ in width. Water from Kepayang River flows to Sebangan River and later to Sadong River and eventually to the South China Sea. The river has very limited excess; that is, only between $2 \mathrm{~km}$ and $4 \mathrm{~km}$ can be explored by boat whereas the rest of the river is covered by overgrown weeds, ferns, herbs (e.g., Hanguana malayana), and other aquatic plants. The river has brown to black colour water and slow flowing or sometime near stagnant, a common character of a peat swamp area. Near to this site, there is a relatively large privately owned oil palm plantation. Both local people and oil palm plantation workers do subsistence fishing along the river.

2.2. Physicochemical Water Quality (WQ) Parameters. Selected physicochemical WQ parameters were measured at each checkpoint of the rivers (Table 1). Temperature and dissolved oxygen (DO) were measured using DO meter Hanna HI9146, $\mathrm{pH}$ was measured using Hanna HI $8314 \mathrm{pH}$ meter, and turbidity was measured using Turbidity Meter 93703 Hanna
Instrument. Water samples for chlorophyll a ( $\mathrm{Chl}$ a), total suspended solids (TSS), and nutrients (i.e., nitrate, nitrite, ammonia, orthophosphate, and silicate) were collected in triplicate at the checkpoints. Chl a and nutrients were measured in the laboratory using Hach Kit DR 2010 machine following standard method whereas TSS was analyzed following the methods of [10]. Habitat descriptions at study sites were also recorded.

2.3. Estimation of Aquatic Food Resource. In this study, availability and estimation of aquatic food resource in each river were conducted using catch per unit effort (CPUE) approach [11]. Passive fish captured method using three-layer gill nets (length and drop: $15 \mathrm{~m} \times 1.5 \mathrm{~m}$; stretch mesh size: $1.2 \mathrm{~cm}$ and $7.5 \mathrm{~cm}$; deployment time: between $7 \mathrm{am}$ and $10 \mathrm{am}$ ) had been carried out accordingly in each river. Fish catches were examined and identified to species level using available references such as FishBase [12].

2.4. Local Knowledge. This study employed semistructured questionnaires (testimonies and personal accounts related to Tomistoma) on the local people. Interviews were carried out on mixture of senior citizens and people from the new generation within the sampling sites according to [13]. Interviews were based around the following topics and questions:

(i) Where can Tomistoma be seen in this area; name of rivers/lakes/areas?

(ii) When was the last time Tomistoma was seen in the area?

(iii) When is the best time to see Tomistoma (wet/dry/ special time of year)?

(iv) What size of the Tomistoma that you saw (estimate size; adult, juvenile, young, hatchling)? 


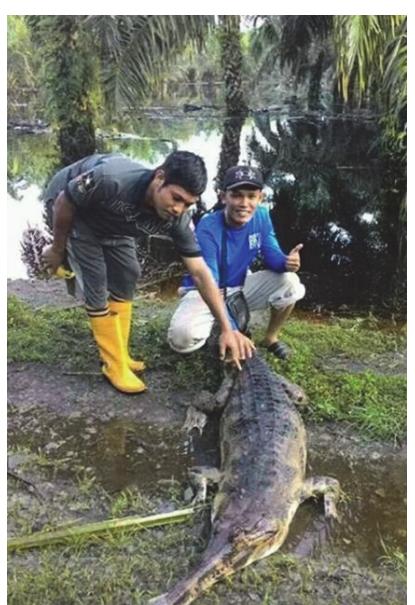

FIGURE 2: Tomistoma caught on 9/2/15 in Samarahan River tributary (total length $=2.4 \mathrm{~m}$ ).

(v) How often do you see Tomistoma (every year, wet, dry, every time out fishing)?

(vi) Have you ever heard any stories of Tomistoma being seen, caught, killed by someone else? Which area was this, dates, details?

(vii) Any nests or babies seen? Have you heard any stories of young Tomistoma (description, nest, habitat, clutch size, nest type)?

\section{Results and Discussion}

3.1. Survey Results. In this study, no Tomistoma was seen in all rivers (Table 1) although many stretches of the rivers seem to be potential Tomistoma habitats [8]. Negative result obtained during this study most probably is due to (i) the nature of Tomistoma who are very secretive and wary about any disturbances, (ii) surveys done only during day light, (iii) relatively short time spent on boat and foot surveys in each river, and (iv) rivers involved being relatively difficult in terms of accessibility. Day time search is believed to be among the main reasons of zero sighting; thus, future work will involve night surveys.

3.2. History of Sightings/Captured Tomistoma. Table 2 summarized the history of captured Tomistoma and sightings from local people.

On 9th February 2015, one adult male Tomistoma (Figure 2, Table 2) had been captured in tributary of Samarahan River. Local people claimed that some parts of Samarahan River supported small population of Tomistoma in the 1970s and 1980s but they had never seen this animal in the recent years.

Overall, Tomistoma caught on 9th February 2015 seemed healthy with good body weight-length proportion and had good skin condition and patterns. However, there was a slight infection on both eyes, in which left eye was relatively red in colour. Debris of fishing net was found entangled in its mouth. Slight bleeding was also seen on the left and right

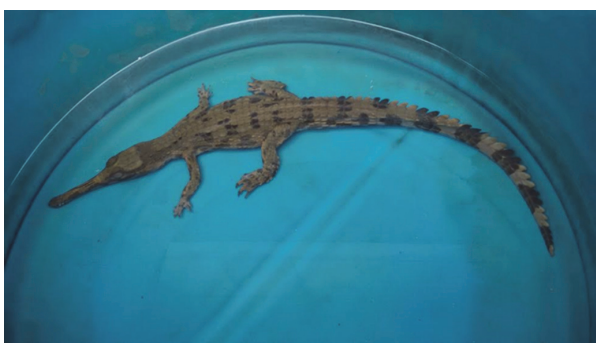

FIgUre 3: Tomistoma caught in March 2015 at Bunga-Baki River, Serian (total length $=0.4 \mathrm{~m}$ ).

upper limb legs, as a result from injuries, most probably due to constant struggle to free itself from the nets.

Two individuals of Tomistoma hatchlings were captured in two conservative years in Bunga-Baki River, both in the month of March 2014 and 2015, by a local resident. The first hatchling was released in the same habitat, while the later was sent to Matang Wildlife Centre (Figure 3). The presence of hatchlings in this area suggests that there is a breeding Tomistoma population in the river, which gives hope that there is a bright future for Tomistoma to thrive in this river. Local fishermen interviewed $(n=5)$ and senior citizen $(n=$ 2 ) reported that they once saw adult Tomistoma in 2014.

In Kepayang River, during 22nd-25th July 2014 visit, three out of 10 male villagers who worked as porters and guides claimed that they have seen one young Tomistoma of approximately $1 \mathrm{~m}$ during their recent fishing trip. Local villagers and oil plantation workers claimed that one Tomistoma carcass had been found in May 2014 but the carcass could not be located during the field visit. There was also one reported Tomistoma sighting at Kepayang River during SFC Aquatic Survey Exercise on 28th July 2014, two days after the first visit.

During the second trip to Kepayang River (3rd-4th February 2015), a total of five villagers $(n=5)$ had been interviewed, mixture of male and female from ethnic Iban, who work as either small scale farmers or house makers, aged between 40 and 70 years. This older generation had personal encounter with Tomistoma but mostly during 1970s and 1980s during their boat journey to the nearest town. They are all in agreement that there are Tomistomas in the Kepayang River although none of them meet this animal recently.

On 16th and 17th of February 2016, local people had informed authors that Tomistomas were sighted in Kepayang River, but none were captured although effort to catch Tomistoma using nets, hook, and line had been carried out. It is likely that the presence of aquatic weeds in the river gives advantage to the Tomistoma to shelter themselves.

\subsection{Water Quality}

3.3.1. Selected WQ Parameters. Data obtained during this study (Tables 3 and 4) serve as baseline WQ parameters suitable for Tomistoma habitats in Sarawak. Water temperature, $\mathrm{pH}, \mathrm{DO}$, and turbidity readings (Table 3 ) are typical of peat swamp ecosystem as reported by [14-17]. According to the National Water Quality Standards (Malaysia), except 
TABLE 2: History of Tomistoma sightings or captured Tomistoma (2014-2016).

\begin{tabular}{|c|c|c|c|c|}
\hline Locality & Date & Status & Size/life stage & Person \\
\hline Samarahan & $9 / 2 / 2015$ & $\begin{array}{c}\text { Captured }(n=1) \\
\text { Sent to Matang Wildlife } \\
\text { Centre, died in March } 2015\end{array}$ & $2.4 \mathrm{~m}$ & $\begin{array}{l}\text { Local people and } \\
\text { volunteers }\end{array}$ \\
\hline \multirow{2}{*}{$\begin{array}{l}\text { Bunga-Baki } \\
\text { River }\end{array}$} & March 2014 & $\begin{array}{c}\text { Captured }(n=1) \\
\text { Released by local people in } \\
\text { the same habitat }\end{array}$ & Hatchling & Local people \\
\hline & $12 / 3 / 2015$ & $\begin{array}{c}\text { Captured }(n=1) \\
\text { Sent to Matang Wildlife } \\
\text { Centre }\end{array}$ & $0.4 \mathrm{~m}$ & Local people \\
\hline \multirow{4}{*}{ Kepayang River } & July 2014 & Sighting $(n=1)$ & Subadult & $\begin{array}{l}\text { SFC Aquatic } \\
\text { Survey team }\end{array}$ \\
\hline & July 2014 & Carcass $(n=1)$ & Adult & Plantation workers \\
\hline & $16 / 2 / 2016$ & Sighting $(n=1)$ & Adult & Local people \\
\hline & $17 / 2 / 2016$ & Sighting $(n=1)$ & Adult & Local people \\
\hline
\end{tabular}

*SFC: Sarawak Forestry Corporation.

TABLE 3: Selected water quality parameters measured in situ.

\begin{tabular}{lcccc}
\hline River & Temperature $\left({ }^{\circ} \mathrm{C}\right)$ & $\mathrm{pH}$ & Dissolved oxygen $(\mathrm{mg} / \mathrm{L})$ & Turbidity $(\mathrm{NTU})$ \\
\hline Samarahan & $26.67 \pm 0.57$ & $6.73 \pm 0.47$ & $5.03 \pm 0.47$ & $1.13 \pm 0.12$ \\
Bunga-Baki & $27.77 \pm 0.68$ & $4.20 \pm 0.30$ & $4.23 \pm 0.25$ & $4.40 \pm 0.53$ \\
Kepayang & $27.70 \pm 0.26$ & $5.59 \pm 0.05$ & $4.71 \pm 0.01$ & $2.83 \pm 0.55$ \\
\hline
\end{tabular}

${ }^{*}$ Mean \pm SD.

TABLE 4: Selected water quality parameters measured ex situ.

\begin{tabular}{lccccccc}
\hline River & $\begin{array}{c}\text { Chlorophyll a } \\
(\mathrm{mg} / \mathrm{L})\end{array}$ & TSS $(\mathrm{mg} / \mathrm{L})$ & $\begin{array}{c}\text { Ammonia } \\
\left(\mathrm{mg} / \mathrm{L} \mathrm{NH}_{3}-\mathrm{N}\right)\end{array}$ & $\begin{array}{c}\text { Nitrate }(\mathrm{mg} / \mathrm{L} \\
\left.\mathrm{NO}_{3}-\mathrm{N}\right)\end{array}$ & $\begin{array}{c}\text { Nitrite }(\mathrm{mg} / \mathrm{L} \\
\left.\mathrm{NO}_{2}-\mathrm{N}\right)\end{array}$ & $\begin{array}{c}\text { Orthophosphate Silicate }(\mathrm{mg} / \mathrm{L} \\
\left(\mathrm{mg}^{2} \mathrm{~L} \mathrm{PO}_{4}{ }^{3-}\right)\end{array}$ & $\left.\mathrm{SiO}_{2}\right)$ \\
\hline Samarahan & $0.49 \pm 0.08$ & $19.33 \pm 1.15$ & $0.03 \pm 0.01$ & $0.02 \pm 0.01$ & $0.002 \pm 0.001$ & $0.22 \pm 0.01$ & $0.52 \pm 0.10$ \\
Bunga-Baki & $0.45 \pm 0.12$ & $6.67 \pm 4.16$ & $0.02 \pm 0.01$ & $0.02 \pm 0.01$ & $0.002 \pm 0.001$ & $0.24 \pm 0.04$ & $0.37 \pm 0.14$ \\
Kepayang & $0.57 \pm 0.11$ & $3.00 \pm 1.00$ & $0.21 \pm 0.01$ & $0.05 \pm 0.02$ & $0.005 \pm 0.003$ & $0.32 \pm 0.24$ & $0.79 \pm 0.17$ \\
\hline
\end{tabular}

${ }^{*}$ Mean \pm SD.

for DO and $\mathrm{pH}$, WQ for the three rivers falls in Class I, an indication of clean water, which is suitable for conservation of natural environment as well as habitats for very sensitive aquatic species. Water temperature recorded in this study is similar to those of Lake Mensangat, which supports healthy Tomistoma population in Kalimantan [18]. Bunga-Baki River which supports a breeding population during this study has recorded slightly different WQ compared to the other two rivers (Table 3 ). It has the lowest $\mathrm{pH}$ (average 4.2 ) and the lowest DO (average $4.23 \mathrm{mg} / \mathrm{L}$ ) whereas its turbidity recorded the highest reading (average $4.4 \mathrm{NTU}$ ), thus suggesting that Tomistoma could tolerate acidic water condition, low DO concentration, and moderate turbid water. Other WQ parameters (Table 4) show that Samarahan River and BungaBaki River are in Class I. However, for Kepayang River, ammonia and orthophosphate concentrations fall into Class II. Thus, one may say Tomistoma could live in rivers with a wide range of WQ parameters, either Class I or Class II. WQ readings reported in this study are limited to wet season only; therefore, future work should be carried out during both dry and wet seasons in order to get a better understanding of relationships between water quality and the presence of Tomistoma population.

3.4. Current Status of Aquatic Food Resource. Compared to the Gavialis gangeticus, [2] suggested Tomistomas have a broader diet including relatively large mammals, reptiles, and birds as well as small invertebrates. In addition, [3] reported that plant materials could also be found in stomach of Tomistoma and suggested that Tomistoma is most likely an opportunistic feeder.

During this study, the highest CPUE was recorded in Kepayang River with the value of $1.67 \mathrm{~kg} / \mathrm{h}$, followed by Samarahan River $(0.5 \mathrm{~kg} / \mathrm{h})$ and finally Bunga-Baki River $(0.2 \mathrm{~kg} / \mathrm{h})$. However, compared to [19] results, the three rivers involved in this study have relatively low CPUE values. Reference [19] had recorded mean CPUE for Sblak River (Sibu), Bako-Buntal-Santubong River (Kuching), Sibuti River (Miri), and Similajau River (Bintulu) as $1.14 \mathrm{~kg} / \mathrm{h}, 2.01 \mathrm{~kg} / \mathrm{h}$, $2.68 \mathrm{~kg} / \mathrm{h}$, and $2.42 \mathrm{~kg} / \mathrm{h}$, respectively. The authors also noted that rivers in National Parks, where traditional fishing is only allowed to local people, have relatively higher CPUE values 
TABLE 5: Checklist of fish in Samarahan River, Bunga-Baki River, and Kepayang River.

\begin{tabular}{|c|c|c|c|c|c|}
\hline \multirow{2}{*}{ Family } & \multirow{2}{*}{ Species } & \multirow{2}{*}{ Local name } & \multicolumn{3}{|c|}{ River } \\
\hline & & & Samarahan & Bunga-Baki & Kepayang \\
\hline Anabantidae & Anabas testudineus & Puyu & + & + & + \\
\hline Channidae & Channa striata & Haruan & - & + & + \\
\hline Cichlidae & Oreochromis mossambica & Tilapia & + & + & + \\
\hline Clariidae & Clarias batrachus & Keli kayu & + & - & - \\
\hline Helostomatidae & Helostoma temminckii & Biawan & + & + & + \\
\hline \multirow{2}{*}{ Osphronemidae } & Trichopodus trichopterus & Sepat & + & + & + \\
\hline & Trichopodus pectoralis & Sepat Siam & + & + & + \\
\hline Siluridae & Wallago attu & Tapah & - & - & + \\
\hline
\end{tabular}

of around $7.67 \mathrm{~kg} /$ hour. CPUE value is one of the approaches to determine status of fish resources in a particular river but this does not involve the abundance of other aquatic food sources; thus, data presented here should be handled with caution. Checklist of the freshwater fish species caught at each sampling site is in Table 5. The species caught in this study are typical of peat swamp fish, similar to those reported by $[16,20]$. In general, Kepayang River has larger fish size, for example, the wallago, Wallago attu. Majority of fish caught during this study have commercial importance; thus, the rivers are important assets to local communities. Small scale fishing can be observed in all three rivers involved in this study; thus, one may say fishing activities cause very minor disturbance to Tomistoma food source. Based on interviews carried out with local people during this study, they put high value on the rivers and very minor changes happened to the rivers locally for the last 30 years. However, all respondents agreed that changes are unavoidable in other rivers connected to their rivers or in the upstream areas, for example, conversions of natural forest to big scale oil palm plantation which in turn affect the ecology of the rivers. Over time, wild Tomistoma populations in the rivers will be affected severely, in support of [6] claim that threats to Tomistoma came mostly from conversion of peat lands and pandan swamps into agriculture, not due to hunting.

\section{Conclusion}

All three rivers involved in this study show presence of wild population of Tomistoma based on captured individuals as well as recent reports of Tomistoma sightings by the local people. This study also highlights the presence of a breeding population in Bunga-Baki River; thus, further work is needed to identify the nesting site for appropriate conservation actions to be implemented. This area is significant for Tomistoma conservation in Sarawak. Future surveys and interviews are required in other areas in Sarawak to get a better understanding of the status of Tomistoma in the state.

\section{Competing Interests}

The authors declare that they have no competing interests.

\section{Acknowledgments}

This work is supported by the Ministry of Education Malaysia through fundamental Research Grant Scheme FRGS/STWN $10(01) / 1066 / 2013$ (12), awarded to the first author. The authors would like to thank UNIMAS for laboratory facilities and transportation. Thanks are due to Forestry Department, Sarawak, for granting permits to conduct research on biological resources (Permit no. NCCD.907.4.4.4 (jld.10)-255 and Park Permit no. 263/2014).

\section{References}

[1] M. R. Bezuijen, B. Shwedick, B. K. Simpson, A. Staniewicz, and R. Stuebing, "Tomistoma schlegelii. The IUCN Red List of Threatened Species. Version 2014.3," 2014, http://www iucnredlist.org/.

[2] M. R. Bezuijen, G. J. W. Webb, P. Hartoyo, R. W. S. Samedi, and S. C. Manolis, "The false gharial (Tomistoma schlegelii) in sumatra," in Proceedings of the 14th Working Meeting of the IUCNSSC Crocodile Specialist Group (IUCN '98), pp. 31-31, Gland, Switzerland, 1998.

[3] R. B. Stuebing, M. R. Bezuijen, M. Auliya, and H. K. Voris, "The current and historic distribution of Tomistoma schlegelii (the False Gharial) (Müller, 1838) (Crocodylia, Reptilia)," The Raffles Bulletin of Zoology, vol. 54, no. 1, pp. 181-197, 2006.

[4] J. H. Cox and F. Gombeck, "A preliminary survey of the crocodile resource in sarawak East Malaysia," IUCN/WWF Project MAL 74/85, World Wildlife Fund Malaysia \& the National Parks and Wildlife Office, Forest Department, Sarawak, Malaysia, 1985.

[5] A. C. Sebastian, "The Tomistoma schlegelii in Southeast Asia: a status review and priorities for conservation," in Proceedings of the 12th Working Meeting of the Crocodile Specialist Group, vol. 1 of IUCN, The World Conservation Union, Gland, Switzerland, 1994.

[6] R. B. Steubing, S. A. M. Sah, E. Lading, and J. Jong, "The status of Tomistoma schlegelii (Mueller) in Malaysia," in Proceedings of the 17th Working Meeting of the IUCN-SSC Crocodile Specialist Group, pp. 136-140, IUCN, Gland, Switzerland, 2003.

[7] A. Pine, "Tomistoma, False Gharial, Sunda Gavial (Tomistoma schlegelii)," A Report for Mohamed bin Zayed Species Conservation Fund, Project Number 12255301, 2013. 
[8] R. B. Steubing, E. Lading, and J. Jong, "The status of the false gharial (Tomistoma schlegelii) in Sarawak," in Proceedings of the 14th Working Meeting of the IUCN-SSC Crocodile Specialist Group, IUCN, Gland, Switzerland, 1998.

[9] R. Hassan and M. I. Z. A. Gani, "Crocodiles in Western of Sarawak, Malaysia," in Proceedings of the 22nd Working Meeting of the IUCN SSC Crocodile Specialist Group, World Crocodile Conference, pp. 90-95, Negombo, Sri Lanka, May 2013.

[10] APHA, Standard Methods for Examination of Water and Wastewater, American Public Health Association, Washington, DC, USA, 2005.

[11] J. A. Gullan, Manual of Methods for Fish Stock AssessmentPart 1. Fish Population Analysis, vol. 1, Food and Agriculture Organization of the United Nations, Rome, Italy, 1969.

[12] R. Froese and D. Pauly, "FishBase," Electronic database, 2012, http://www.fishbase.org/.

[13] B. K. Simpson, Status Assessment of Tomistoma in Peninsular Malaysia: Peat Swamp Forests of Selangor \& Pahang, Tomistoma Task Force, of the IUCN/SSC Crocodile Specialist Group, 2014.

[14] M. B. Gasim, B. S. Ismail, E. Toriman, S. I. Mir, and T. C. Chek, "A physico-chemical assessment of the Bebar River, Pahang, Malaysia," Global Journal of Environmental Research, vol. 1, no. 1, pp. 7-11, 2007.

[15] K. Irvine, S. Vermette, and F. B. Mustafa, “The 'Black Waters' of Malaysia: tracking water quality from the peat swamp forest to the sea," Sains Malaysiana, vol. 42, no. 11, pp. 1539-1548, 2013.

[16] K. A. A. Rahim, S. K. Daud, S. S. Siraj, A. Arshad, Y. Esa, and E. R. Ibrahim, "Freshwater fish diversity and composition in Batang Kerang floodplain, Balai Ringin, Sarawak," Pertanika Journal of Tropical Agricultural Science, vol. 32, no. 1, pp. 7-16, 2009.

[17] A. K. Sayok, S. Lau, and R. Blanda, "Impact of land-use on Bunut Lake, Sarawak, Malaysia," in Proceedings of the 13th World Lake Conference, Wuhan, China, November 2009.

[18] A. Staniewicz, Diet and demography of Tomistoma schlegelii in Mesangat Lake, East Kalimantan Indonesia, 2011.

[19] J. Bali, T. R. Munsang, T. Ganyai, K. Bakir, and J. Jomis, Current Status of Aquatic Food Resources in Sarawak, Malaysian Borneo. Oral presentation during Borneo Crocodile Forum 2014Human-Crocodile Co-existence, Roadmap to Sustainability, Sibu, Sarawak, 2014.

[20] E. M. Dosi, L. Nyanti, and J. Grinang, "The blackwater fishes of oil palm plantation in Betong, Sarawak," in Proceedings of the Regional Taxonomy and Ecology Conference (TEC '15), 2015. 

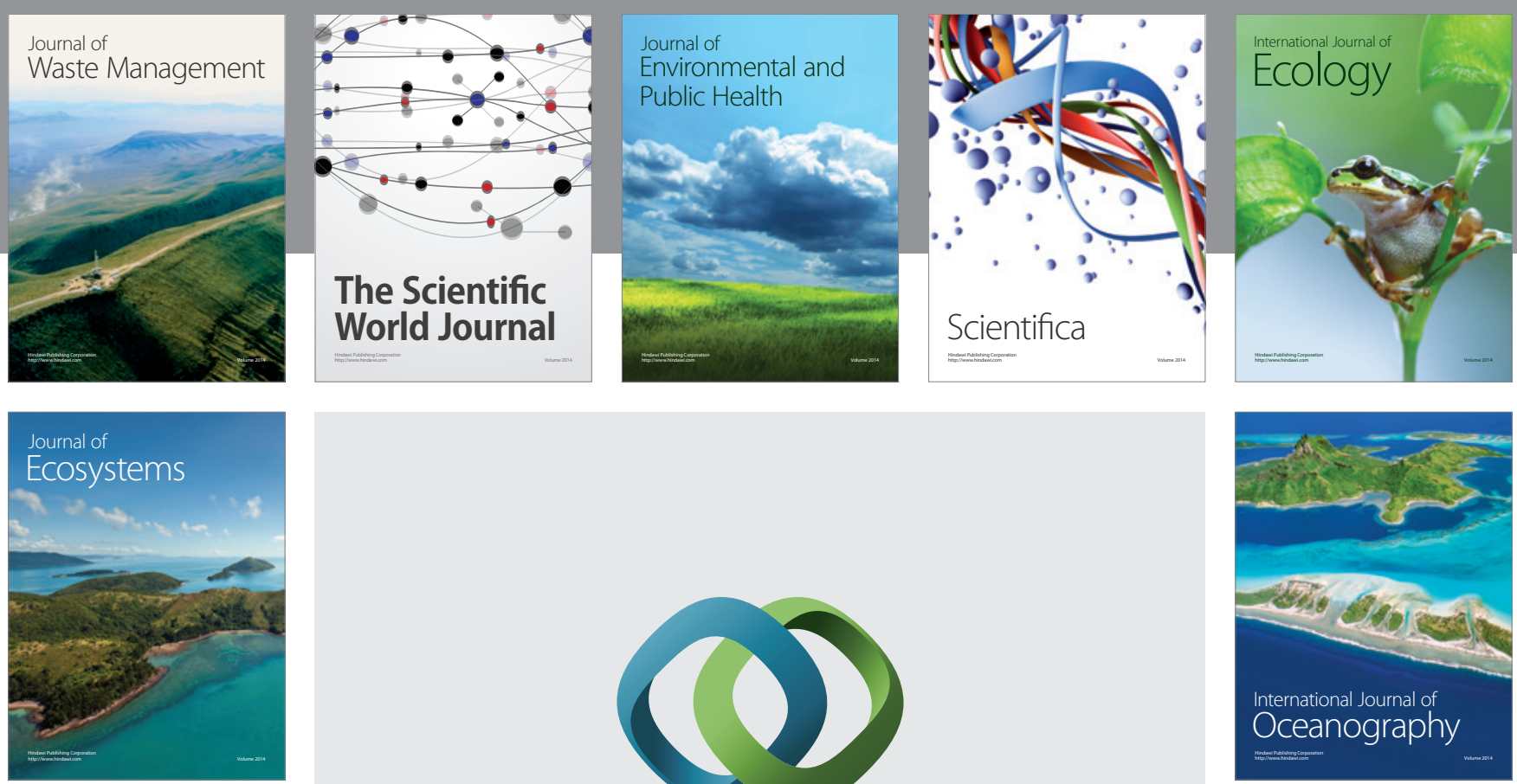

The Scientific World Journal
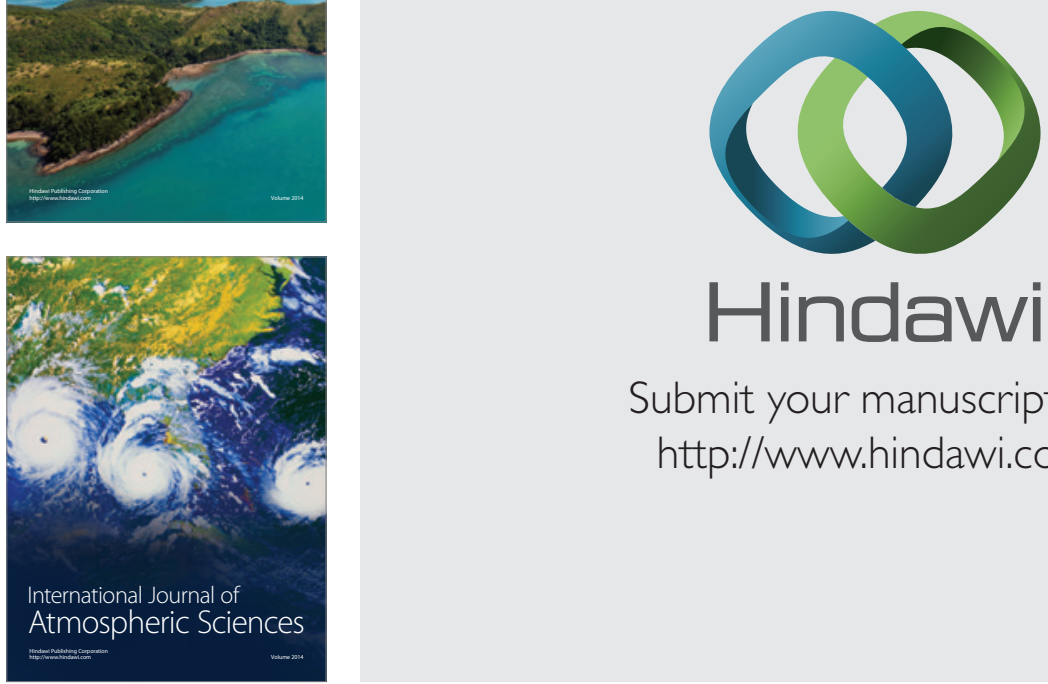

\section{Hindawi}

Submit your manuscripts at

http://www.hindawi.com
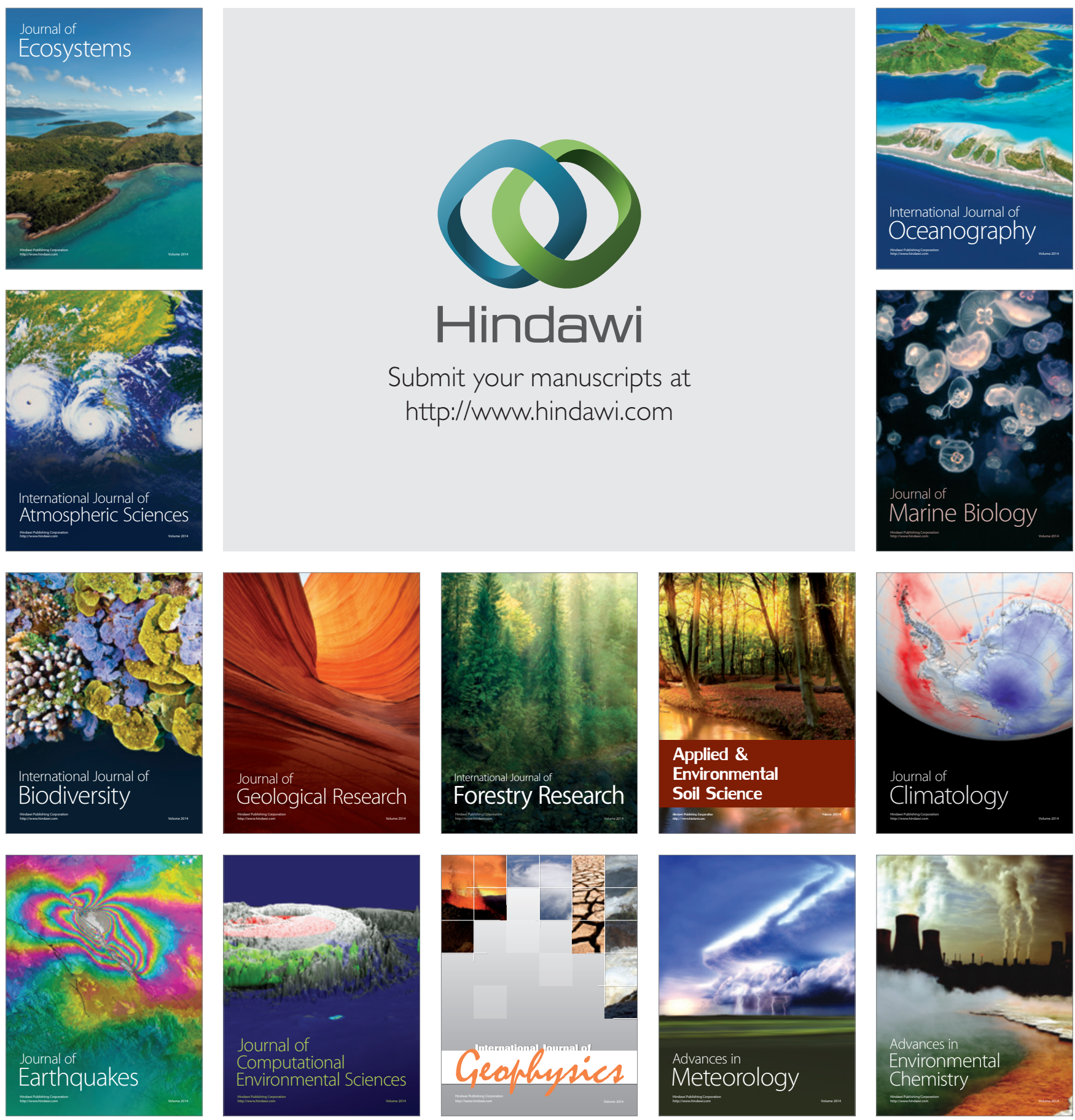